\title{
How Far Do Salary Satisfaction, Marital Status And Gender Moderate The Effect On Employees' Internal Work Motivation And Organizational Commitment To Employees' Work Performance In Hospitality Industry in Indonesia?
}

\author{
$1^{\text {st }}$ Hani Ernawati \\ Departement of Management \\ Sekolah Tinggi Pariwisata Ambarruko \\ (Ambarrukmo Tourism Institute) \\ Yogyakarta, Indonesia \\ email: hani_ernawati@yahoo.com
}

\author{
$2^{\text {nd }}$ Zainnur M. Rusdi \\ Departement of Human Resource \\ Management \\ University of Lampung \\ Lampung - South Sumatra, Indonesia \\ email: zainnur@gmail.com
}

\begin{abstract}
There is now a substantial evidence to determine what moderates how employees in hospitality industry stimulated to increase their internal work motivation and their organizational commitment, and salary satisfaction appears to be a useful way to conceptualize and measure it.

The purposes of this study are - 1).to investigate the effect of emplooyes's internal work motivation and organizational commitment to employees's work performance, 2). to analize the moderating effect of salary satisfaction, marital status, and gender in the interaction of employees' internal work motivation and organizational commitment on work performance.

Design/methodology/approach - A questionnaire was directed toward 172 hotel workers in Yogyakarta, Indonesia.

Findings - The current study examines internal work motivation, organizational commitment and work performance, and specifically whether there are moderating effect of salary satisfaction, marital status and gender. Results showed, as expected, positive relationship betweeninternal work motivation, organizational commitment and work performance and do interact with salary satisfaction and marital status to influence job performance, but not gender, there is no moderating effect of gender on these positive relationships.

Practical implications - The study provides an assessment of hotel workers' performance, and offers useful insights on how work performance should be improved. Salary satisfaction is proposed to boost it up through increasing employees' work motivation and their commitment to their roganization. Manager should also give more attention to employees' marital status that has a positive effect on employees' motivation, commitment, and performance.
\end{abstract}

Keywords-: internal work motivation, organizational comitment, work performance, salary satisfaction, marital status, gender, moderating effect.

\section{INTRODUCTION}

By the fact that hospitality industy is the potential leading sector of Indonesia in the years to come, whereas the contribution of human resource is the most important factor to increase the number of tourists, it is important to increase employees' work performance in hospitality industry through the increasing of the affecting factos such as internal work motivation and organizational commitment that will be predicted to affect employees' work performance positively.

Labor market discrimination is a situation in which an otherwise identical person is treated differently by virtue of that person's gender or race. A large part of the literature on labor market discrimination focuses on the problem of gender salary gap. But, by the fact that gender salary gap is reducing over time (Maria \& Takahashi, 2011)

There is now a substantial evidence to determine what moderates how employees in hospitality industry stimulated to increase their internal work motivation and their organizational commitment, and salary satisfaction appears to be a useful way to conceptualize and measure it. The basic prediction is that people who have high need for higher salary will respond more positively to their job and high in motivation and in high commitment, in the other word salary satisfaction makes people increase their internal work motivation and organizational commitment then attain high work performance as the positive impact.

The purposes of this study are ;1).to investigate the effect of emplooyes's internal work motivation and organizational commitment to employees's work performance, 2). to analize the moderating effect of salary satisfaction, marital status, and gender in the interaction of employees' internal work motivation and organizational commitment on work performance.

The model focuses on the interaction between threeclasses of variables (a) employees' internally motivated work behavior that are presented in their psychological states, (b) salary satisfaction, (c) employees' work performance that are presented by the management's assesment. 


\section{LITERATURE REVIEW}

\section{a. Relationship Between Internal Work Motivation and Work Performance}

There are three psychological states that presents employees' internally motivated work behavior are : experienced meaningfulness of the work, experienced responsibility for the outcomes of the work and knowledge of the results of the work activities. experienced meaningfulness of the work : the degree to which the individual experiences the job as one which is generally meaningful, valuable, and worthwhile. Experienced responsibility for work outcomes: The degree to which the individual feels personally accountable and responsible for the results of the work he or she does. Knowledge of results: The degree to which the individual knows and understands, on a continuous basis, how effectively he or she is performing the job. (Hackman \& Oldham, 1976).

\section{b. Relationship Between Internal Organizational Commitment and Work Performance}

Organizational commitment is actively involved in the organization, individual organizations are willing to dedicate their effort, and it is not only in thoughts and beliefs of the members of the organizations, which is also reflected in the behavior. (Y. Lee \& Lee, 2018). Organizational commitment is devided into : affective commitment, continuance commitment, normative commitment. Affective commitment (AC) such as trust safe conditions, fair compensation, that employees exchange good treatment by the firm (e.g.,) for their affective attachments, are the stronger attachments result in more favorable job performance. Those effects are often explained in a social exchange framework. (Sinclair, Tucker, Cullen, \& Wright, 2005) AC concerns employees' emotional attachments to their organizations. Employees with strong $\mathrm{AC}$ believe their values match those of their employer and feel emotionally attached to and identify with their company. Continuance commitment (CC) refers to perceptions that the leaving costs of the organization exceeds the remaining costs. Originally proposed that people engage in consistent lines of behavior because of the inducements (side bets) to do so. Employers offer a variety of such inducements to retain employees, including job status, seniority, and benefits. Further, employees often desire to avoid the social and economic costs of leaving (e.g. relocation costs, disrupted social networks). CC strengthens as these side bets accumulate, rendering employees more likely to stay with the organization. Higher CC often is assumed to be undesirable, because studies frequently show that it is negatively or unrelated to job performance and citizenship behavior (Sinclair et al., 2005). And other three dimensions. Thus, the reason why employees want to do so; sustained commitment of employees, because they need to do so; and there are normative commitments employees is because they think it ought to do so. (Y. Lee \& Lee, 2018). Our commitment scales involve two items for each of the five potential foci, reflecting loyalty and value congruence.
This is attitudinal rather than behavioural commitment (Redman, 2005).

\section{c. Relationship Between Salary satisfaction and Work Performance}

Salary satisfaction is defined as the degree to which employees are satisfied with their current salary. More specifically, employees compare the efforts they make with the salary they get and with others' salary and then decide how much efforts they will make at work. If the salary is lower than others, they will be less committed to their work in order to avoid salary dissatisfaction. A good salary policy can attract and retain talents, preventing employees from leaving their companies due to salary dissatisfaction. Since firms use salary as reward for the efforts of their employees at work, they should be thoughtful about their salary design and method, following certain important principles such as fairness and motivating factors $(\mathrm{H}$. Lee, Lin, Lee, \& Lin, 2014)

Salary satisfaction means comprehensive personal attitudes or feelings arising from their own salary, whether positive or negative attitudes or feelings. Salary satisfaction is devided into five parts : salary system, salary structure, a sense of fair wages, intrinsic motivation, and welfare policies. (Y. Lee \& Lee, 2018)

Worker performance improves between those who move onto salaried contracts relative to those who do not. The size of the performance gap betweenreferees on salaried contracts and those on match fees is potentially informative with respect to the different mechanisms by which the salary effect occurs. Improved performance could arise from the additional effort workers exert due to career concerns, the higher income associated with career contracts (an efficiency wage effect) or improvements in worker quality arising from off-the-job training which accompanies the salaried contracts (Bryson, Buraimo, \& Simmons, 2011).

\section{d. Relationship Between Gender and Performance}

There is apositive effect of gender diversity on performance (including complementarities, learning, monitoring and confliicts) but find no support for them. Business teams with an equal gender mix perform better than male-dominated teams in terms of sales and products. (Torres, Fu, \& Lehto, 2014).Selmer (2009) found that there was no moderating effect of gender on the positive relationship between being married and the work outcomes may have something to do with the type of expatriates studied. Although being married has a positive association with work effectiveness as well as with work performance but, surprisingly, there is no moderating effect of gender either on these positive relationships or on the positive association between being married and the two studied work outcomes, work efficiency and work performance (Selmer \& Lauring, 2009). Gender contributed $11 \%$ to the total beta weight in enhancing job satisfaction and performance. The implication is that job performance can be predicted by gender roles (State, 2010). 
Rowold, in the study of 'the moderating role of a work team's level of age, gender, and cultural heterogeneity relationship between leadership behaviors and performance', revealed that the interaction between consideration and work teams' heterogeneity (i.e. with regard to gender) was significantly related to performance. As a speculation, team members of heterogeneous work teams not only elicit individualized considerate behavior from their leaders, but also utilize this one-on-one guidance to achieve work-related goals and high performance (Rowold, 2007)

\section{e. Relationship Between Gender and Salary Satisfaction}

Men and women have been shown to negotiate different salary amounts, but little research has investigated whether their behavior differs and how their beliefs might affect behavior. There are differences in the nature of men's and women's beliefs about requesting a higher salary, men made significantly larger salary requests than women and that beliefs were related to these requests. It is likely that men's and women's salary negotiation behavior is multiply determined. Beliefs about the self, entitlement, other opportunities and one's value in the workplace are likely to have an impact on salary negotiation behavior, with beliefs about entitlement being more proximally related to behavior There was no relationship between gender and job performance founded in the prior studies.(Barron, 2003).

Figure 1. The Proposed Model Of The Moderating Effect Of Salary Satisfaction, Marital Status, And Gender Between Internal work motivation, Organizational Commitment and Work Performance

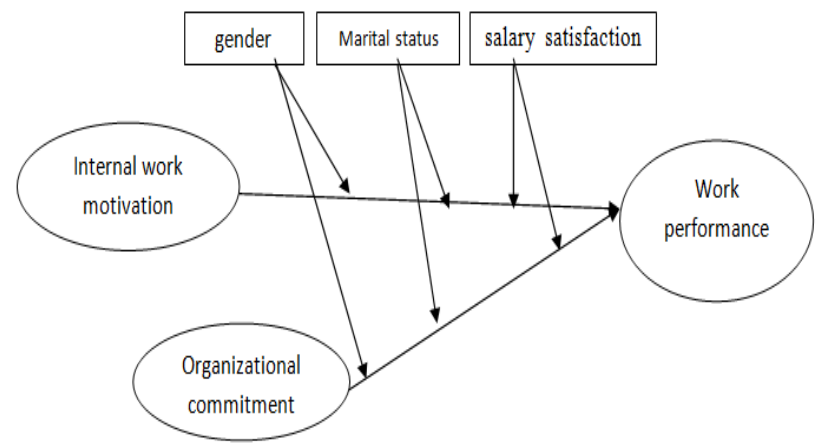

Hyphotesis 1. Employees' internal work motivation has a positive effect on work performance

Hyphotesis 2.organizational commitment has a positive effect on work performance

Hyphotesis 3. As salary satisfaction increases, the positive effect of internal work motivation on mean work performance increases.
Hyphotesis 4. As salary satisfaction increases, the positive effect of organizational commitment on work performance increases.

Hyphotesis 5. Marital status moderates the effect of organizational commitment and employees' internal work motivation effects work performance.

Hyphotesis 6. Gender moderates the effect of the organizational commitment and employees' internal work motivation on work performance.

\section{METHOD}

\section{a. Samples and Procedur}

A total of 172 respondents were collected and analyzed for the current hotel employees' survey. They consisted of managers and their subordinates at the hotels ranged of three to five star. They were asked to make self-assessments on their internal motivation and organizational commitment in a 5-point Likert scale, ranged of 1 to 5 (1_totally disagree to 5 _totally agree), then we investigated the effects of salary satisfaction on their work performance. They were asked to assess their satisfaction on their salary. Whereas, managers were asked to asses their subordinates' performance.

We conducted a series of OLS regressions to understand the relationship between employees' internal work motivation and organizational commitment to work performance, and the effect of salary satisfaction, marital status, and gender of the relationship of them.

\section{b. Measure}

The survey provided respondents with three indicator of internal work motivation, (1) Experienced meaningfulness of the work (2), Experienced Responsibility for Work Outcomes, (3) Knowledge of Results. Typical questionnaire items measuring it include: (a) I feel a great sense of personal satisfaction when I do this job well; (b) I feel bad and unhappy when I discover that I have performed poorly on this job; and (c) My own feelings are not effected much one way or the other by how well I do on this job (reversed scoring). (Hackman \& Oldham, 1976). Salary satisfaction were measured by the: (a) salary system, (b) salary structure, (c) a sense of fair wages. (Lee \& Lee, 208)

Members of Supervisor will be asked to rate their subordinates' work performance on (a) effort expended on the job, (b) work quality, and (c) work quantity. The ratings were made on five - point scales developed specifically for research purposes (Hackman \& Oldham, 1976).

\section{FINDINGS}

\section{a. Characteristic of Respondents}

A total of 163 respondents were collected and analyzed for the current workers survey in hotel industry in Yogyakarta, special province of Indonesia, one of the most famous tourist destination in Indonesia. 
Demographic characteristics of them were investigated with regards to their gender and marital status. The majority character of the workers in hotel industry are women $(69,30 \%)$, and married people $(75,20 \%)$. The major type of their organization commitment is continuance commitment $(40,88 \%)$ followed by normative commitment $(39,62 \%)$ and effective commitment $(19,49 \%)$ at least.

TABLE 1. Regression Analysis of Work Performance, Internal Work Motivation, and Organizational Commitment.

\begin{tabular}{lrllrr}
\hline Model & $\begin{array}{l}\text { Cronbach's } \\
\text { Alpha (CA) }\end{array}$ & B & $\delta$ & t-value & Sig.level \\
\hline C & &, 694 &, 186 & 3,721 &, 000 \\
\hline MOT &, 748 & 437 &, 017 & 7,732 &, 000 \\
\hline OC &, 822 &, 476 &, 015 & 8,428 &, 000 \\
\hline
\end{tabular}

Regression analysis result of the relationship between work performance $(\mathrm{CA}=, 704)$, internal work motivation, and organizational commitment presented at table 1 showed that $72,20 \%$ variance of work performance explained by other variables included. However, our results showed that reliabilities of all indicator variables indicating that the reliabilities of these nine items (performance : effort, quality, work load, organization commitmrnt : effective, continuance, normative, and internal work motivation: experienced meaningfulness of the work, experienced responsibility for work outcomes, and knowledge of results) were acceptable with the Cronbach's Alpha > 0,6.

Internal work motivation and organizational commitment significantly related to work performance. Internal work motivation (MOT) and organizational commitment (OC) significantly have the positive effect on work performance. (Hyphotesis 1 and hyphotesis 2 are supported).

The highest $B$ coefficient is $B$ MOT $=0,017$, which showed that internal work motivation has the biggest impact on work performance.

Table 2. The Effects Of Salary Satisfaction, Marital Status, And Gender In The Relationship Betweeninternal Work Motivation. Organizational Commitment, And Work Performance.

\begin{tabular}{|c|c|c|c|c|c|}
\hline Model & B & $\begin{array}{c}\mathbf{R}^{\mathbf{2}} \\
\text { adjusted }\end{array}$ & $\mathbf{F}$ & $\begin{array}{c}\text { t- } \\
\text { value }\end{array}$ & Sig.level \\
\hline \multicolumn{6}{|c|}{ 1. $P=C+\beta 1 M O T+\beta 2 S M O T$} \\
\hline C & 1,620 & \multirow[t]{3}{*}{,332 } & \multirow[t]{3}{*}{41,22} & 7,704 & ,000 \\
\hline SMOT & ,284 & & & 2,754 & ,007 \\
\hline MOT & 333 & & & 3,226 &, 002 \\
\hline \multicolumn{6}{|c|}{$P=C+\beta 1 O C+\beta 2 S O C$} \\
\hline C & 1,896 & \multirow[t]{3}{*}{,397 } & \multirow[t]{3}{*}{54,433} & 13,143 & ,000 \\
\hline SOC & ,256 & & & 2,543 & ,012 \\
\hline OC & ,413 & & & 4,099 & 000 \\
\hline \multicolumn{6}{|c|}{$P=C+B 1 M O T+B 2 M M O T$} \\
\hline C & 1,462 & \multirow[t]{2}{*}{,320 } & \multirow[t]{2}{*}{39,102} & 7,358 & ,000 \\
\hline MMOT &, 155 & & & 2,159 & 032 \\
\hline
\end{tabular}

\begin{tabular}{|c|c|c|c|c|c|}
\hline MOT & 490 & & & 6,832 & 000 \\
\hline \multicolumn{6}{|c|}{$P=C+B 1 O C+B 2 M O C$} \\
\hline $\mathrm{C}$ & 1,769 &, 388 & 52,379 & 12,509 & 000 \\
\hline MOC & 479 & & & 7,080 & 000 \\
\hline OC & 254 & & & 3,756 & 000 \\
\hline \multicolumn{6}{|c|}{$P=C+B I M O T+B 2 G M O T$} \\
\hline C & 1,410 &, 305 & 36,624 & 7,082 & ,000 \\
\hline GMOT & 073 & & & 1,111 & ,268 \\
\hline MOT & 546 & & & 8,258 &, 000 \\
\hline \multicolumn{6}{|c|}{$P=C+B 1 O C+\beta 2 G O C$} \\
\hline $\mathrm{C}$ & 1,752 & \multirow[t]{3}{*}{,340 } & \multirow[t]{3}{*}{42,787} & 11,934 & 000 \\
\hline GOC & .078 & & & 1.220 & .224 \\
\hline OC & 576 & & & 8,959 & 000 \\
\hline \multicolumn{6}{|c|}{$\begin{array}{l}\text { Dependent variable } ; \mathrm{P}=\text { work performance. } \\
\mathrm{S}=\text { salary satisfaction; } \mathrm{M}=\text { marital status } ; \mathrm{G}=\text { gender } \\
\text { SMOT = salary satisfaction } \mathrm{x} \text { motivation } \\
\mathrm{SOC}=\text { salary satisfaction } \mathrm{x} \text { organizational commitment } \\
\text { MMOT = marital status } \mathrm{x} \text { motivation } \\
\text { MOC = marital status } \mathrm{x} \text { organizational commitment } \\
\text { GMOT = gender } \mathrm{x} \text { motivation } \\
\text { GOC = gender } \mathrm{x} \text { organizational commitment. }\end{array}$} \\
\hline
\end{tabular}

Salary satisfaction and marital status of the interaction of the organizational commitment and employees' internal work motivation positively effect work performance. (hyphotesis 3,4 and 4 are supported), but not gender (hyphotesis 6 is not supported).

The effect of marital status on the relationship between organizational commitment and work performance is highest betweenst other moderating variables have, indicated by tstatistic of 7,080.

\section{GENERAL DISCUSSION}

Our result showed that internal work wotivation and organizational commitment do interact with salary satisfaction to influence job performance. The higher employees' salary satisfaction causes the positive effect on both employees' work motivation and their commitment to organization, which associated with their work performance, marital status as well, but not gender.

In the other words, increasing on salary satisfaction leads to better performance through the increasing on motivation and orgnizaional commitment.

Furthermore, workers' marital status strenghten the impact positively on the relationship either between work motivation and organizational commitment to work performance. The responsibility to their family contributes greatly need for higher work performance to get much more payment. They are worried about lossing their job, so that they improve their effort, work quality, and job loading. Doing their job as it should be.

Whereas, gender of the interaction of the organizational commitment and employees' internal work motivation doesn't effect work performance.In the other words, internal work motivation and organizational commitment don't interact with gender to influence job performance.

The equal opportunity in the workplace in hospitality industry may make them have the same effort, job loading 
and organizational commitment to deliver their best work performance.

Marital status has the highest effect on the relationship between organizational commitment and work performance. Whereas the effect of salary satisfaction of the interaction of organizational commitment to work performance is the lowest one. It is indicates that monetary reward doesn't be the most important factor influences organizational commitment in hospitality. This finding corroborates the employees' characteristic determined who are continuance (according to what people want to do) and normative type of organizational commitment (what people think ought to do ) (Y. Lee \& Lee, 2018).

The paper suffers from several limitations. First, the lack of representative sample of workforces and the most concerning in the relationships between variables, rather than with the levels of organizational commitment and work motivation of the workers means that our conclusions are likely to be less susceptible to any response bias. Second, the lack of performance indicators provided by managers makes the assesment of the whole employees' performance is limited.

Future research should give more attention on the level number of workers' job grade, which may represent accurately the difference of motivation and commitment. Wider surveyed location might also will produce better generalization of the research result.

Practical implications - The study provides an assessment of hotel workers' performance, and offers useful insights on how work performance should be improved. Salary satisfaction is proposed to boost it up through increasing employees' work motivation and their commitment to their roganization. Manager should also give more attention to employees' marital status that has a positive effect on employees' motivation, commitment, and performance.

\section{ACKNOWLEDGMENT}

This paper was presented in One Belt One Road One Tourism hold on November 22-24, 2018, provided by Palembang Polytechnic of Tourism.

\section{REFERENCES}

Barron, L. A. (2003). Ask and you shall receive ? Gender differences in negotiators' beliefs about requests for a higher salary, 56(200306), $635-662$

Bryson, A., Buraimo, B., \& Simmons, R. (2011). Do salaries improve worker performance? Labour Economics, 18(4), 424-433. https://doi.org/10.1016/j.labeco.2010.12.005

Hackman, R., \& Oldham, G. R. (1976). Motivation through the Design of Work : Test of a Theory, 9(170).

Lee, H., Lin, M., Lee, H., \& Lin, M. (2014). A study of salary satisfaction and job enthusiasm - mediating effects of psychological contract A study of salary satisfaction and job enthusiasm - mediating effects of psychological contract, (November), 37-41. https://doi.org/10.1080/09603107.2013.829197
Lee, Y., \& Lee, D. (2018). The Moderating Effects Of Salary Satisfaction And Working Pressure On The Organizational Climate , Organizational Commitment To Turnover Intention, 19(1), 103-116.

Maria, A., \& Takahashi, S. (2011). Economics of Education Review Gender salary differences in economics departments in Japan. Economics of Education Review, 30(6),1306-1319. https://doi.org/10.1016/j.econedurev.2011.06.002

Redman, T. (2005). Unpacking Commitment: Multiple Loyalties and Employee Behaviour Unpacking Commitment: Multiple Loyalties and Employee Behaviour *, (May 2016). https://doi.org/10.1111/j.1467-6486.2005.00498.x

Rowold, J. (2007). Relationship between leadership behaviors and performance The moderating role of a work team' $s$ level of. https://doi.org/10.1108/01437731111161094

Selmer, J., \& Lauring, J. (2009). Marital status and work outcomes of selfinitiated expatriates Is there a moderating effect of gender? https://doi.org/10.1108/13527601111126021

Sinclair, R. R., Tucker, J. S., Cullen, J. C., \& Wright, C. (2005). Performance Differences Among Four Organizational Commitment Profiles, 90(6), 1280-1287. https://doi.org/10.1037/00219010.90.6.1280

State, E. (2010). Influence of Emotional Intelligence and Gender on Job Performance and Job Satisfaction among Nigerian Policemen, 2(3), $147-154$.

Torres, E. N., Fu, X., \& Lehto, X. (2014). Are there gender differences in what drives customer delight? Tourism Review, 69(4), 297-309. https://doi.org/10.1108/TR-04-2014-0012 